\section{J I T A A}

Journal of the Indonesian Tropical Animal Agriculture Accredited by Ditjen Penguatan Risbang No.60/E/KPT/2016
J. Indonesian Trop. Anim. Agric. pISSN 2087-8273 eISSN 2460-6278 http://ejournal.undip.ac.id/index.php/jitaa 46(4):336-346, December 2021 DOI: $10.14710 /$ jitaa.46.4.336-346

\title{
Supplementation of garlic powder and Lactobacillus casei to improve nutrient digestibility, physiological conditions, and performance of broiler during starter phase
}

\author{
I. Mangisah ${ }^{1,2, *}$, V. D. Yunianto ${ }^{1}$, S. Sumarsih ${ }^{1}$ and S. Sugiharto $^{1}$ \\ ${ }^{1}$ Department of Animal Science, Faculty of Animal and Agricultural Sciences, \\ Diponegoro University, Semarang 50275, Central Java, Indonesia \\ ${ }^{2}$ Vocational School, Diponegoro University, Semarang, Central Java, Indonesia \\ Corresponding E-mail: istnamangisah@yahoo.co.id
}

Received February 26, 2021; Accepted September 11, 2021

\begin{abstract}
ABSTRAK
Penelitian bertujuan untuk mengkaji pengaruh campuran tepung bawang putih dan Lactobacillus casei (GLC) terhadap perkembangan usus, parameter hematologi, kecernaan nutrien dan performa ayam pedaging periode starter. Seratus empat puluh ekor ayam broiler umur 1 hari dibagi menjadi empat kelompok yaitu kontrol (tidak diberikan suplemen GLC) dan diberikan suplemen GLC pada level 1, 2dan 3\% dari total pakan. Ayam dipelihara selama 21 hari di kandang terbuka. Pada hari ke-21, dilakukan pengambilan darah, bobot organ limfoid, dan organ pencernaan, serta data performans. Konsumsi pakan akumulatif sampai hari ke 21 tidak berbeda $(\mathrm{P} \leq 0,05)$ antar kelompok perlakuan. Pada penelitian ini terjadi peningkatan $(\mathrm{P} \leq 0,05)$ tinggi vili di jejunum, dan keasaman di duodenum dan sekum, akibat peningkatan $(\mathrm{P} \leq 0,05)$ asam lemak rantai pendek (SCFA; asetat dan propionat). Kecernaan protein dan serat kasar pada ayam yang diberi GLC secara signifikan lebih tinggi $(\mathrm{P} \leq 0,05)$ dibandingkan dengan kelompok kontrol. Suplementasi GLC (1, 2, dan 3\% dari total pakan) secara signifikan meningkatkan pertambahan bobot badan dan memperbaiki $((\mathrm{P} \leq 0,05)$ konversi pakan (FCR). Kesimpulannya, penggunaan GLC selama fase starter dapat meningkatkan kecernaan nutrien, kesehatan usus, dan performa ayam broiler.
\end{abstract}

Kata kunci: Ayam broiler, Bawang putih, Lactobacillus casei, Performa, Fase starter

\begin{abstract}
This study aimed to assess the effect of a mixture of garlic powder and Lactobacillus casei (GLC) on intestinal development, hematological parameters, nutrient digestibility, and performance of broilers in the starter phase. One hundred forty 1-day-old broiler chicks were divided into four groups, namely control (not given GLC supplement) and given GLC supplement either 1\%, 2\%, and 3\% of total feed. Chickens were reared for 21 days in an open cage. On the $21^{\text {st }}$ day of the experiment, blood collection, lymphoid organ and digestive organ weight, and performance data were recorded. Accumu-
\end{abstract}


lative feed intake until day 21 did not differ $(\mathrm{P}>0.05)$ among treatment groups. In this study, there were improvements in the height of villi in the jejunum, and the acidity in the duodenum and caecum, due to the increase of short-chain fatty acids (SCFA: acetate and propionate). Protein and crude fiber digestibility in the GLC-given chickens was significantly higher than in the control group $((\mathrm{P} \leq 0.05)$. GLC supplementation $(1 \%, 2 \%$, and $3 \%$ of total feed) significantly increased body weight gain and improved feed conversion ratio (FCR) $(\mathrm{P} \leq 0.05)$. In conclusion, the use of GLC during the starter phase can improve the nutrient digestibility, intestinal health, and performance of broiler chickens.

Keywords: broiler chicks, garlic, Lactobacillus casei, performance, starter phase

\section{INTRODUCTION}

The starter phase is the initial period for the growth and development of chickens, as well as a critical phase for chickens (Alkie et al., 2019). During the starter phase, the immune and organ systems of the chicken are not functioning optimally. On the other hand, chickens in the starter phase experience very fast growth. For this reason, the optimal nutritional intake is needed to support hyperplasia, the development of chicken organs, and the formation of muscle mass/meat. The body weight in the starter phase greatly determines the final weight of broiler chickens. Administration of antibiotic growth promoters (AGPs) in feeds had usually been applied to support the rapid growth of broiler chickens (Sugiharto, 2016). However, the negative effects of antibiotic resistance in both broiler chickens and broiler consumers have prompted nutritionists to replace AGPs with natural-based additives and immune boosters. Two of the various AGP alternatives, phytobiotics and probiotics drew great interest because they can improve growth, regulate the immune system of broiler chickens, and increase feed efficiency (Sugiharto, 2016; Rahman et al., 2021). One of the phytobiotics that has the potential as a natural additive is Allium sativum or garlic.

Garlic contains 1 - 2\% fructooligosaccharides (FOS) (Dixit et al., 2018), fructan 45.8 to $54.4 \mathrm{~g} / 100 \mathrm{~g}$ (Lisciani et al., 2017), and inulin 20.3 - 36.1 \% (Moshfegh et al. 1999). Garlic, in addition to containing FOS, fructan and inulin as prebiotics, also contains phenolic compounds (70.24 mg / g), organosulfur, and saponins, which can improve the health of the digestive tract (Kothari et al., 2019). Organosulfur acts as an antibacterial, but is well known not to inhibit gram-positive bacteria such as lactic acid bacteria (LAB) (Hill et al., 2018). The phenolic compounds in garlic play a very important role as antioxidants to prevent cell and organ damage from the oxidative process (Gawad et al., 2014; Capasso, 2013). Garlic as a phytobiotic improved nutrient utilization by increasing the secretion of enzymes, antimicrobial, antioxidants, and antiinflammatory activities (Rahman et al., 2021; Wenk, 2003). In previous studies, phytobiotics have been identified as potential candidates that differentially stimulate favorable bacteria growth such as Lactobacilli and Bifidobacteria and decrease the growth of pathogenic bacteria (Jamroz et al., 2003; Ferdous et al., 2019). Considering all the above facts, a nutritional approach was carried out in the present study through a combination of phytobiotics (garlic powder) and probiotics (Lactobacillus casei) as an alternative to promoting the growth of broiler chicks during the starter phase. Previous studies have shown that as a probiotic strain, Lactobacilus casei can adhere to the intestinal mucosa and is able to colonize the gut, by attaching to the host gastrointestinal (GI) mucosa. It also has high efficiency of gut colonization, and promotes the host's epithelium and immune cells (Hill et al, 2018). Lactobacilus casei has been extensively studied as a fermentation starter culture, since it has various functions such as increasing the expression of interleukin 12 in dendritic cell, and preventing the toxic effect induced by particulate matter (Jung et al., 2021). To the best of our knowledge, studies on the combined use of garlic powder and Lactobacillus casei to improve the 
growth and intestinal health of broiler chicks during the starter phase have never been found in the literature.

The purpose of this study was to determine the effect of a mixture of garlic powder and Lactobacillus casei on the growth rate, internal organ development, nutrient digestibility, and physiological conditions of broiler chicks during the starter phase.

\section{MATERIALS AND METHODS}

\section{Preparation of a Mixture of Garlic Powder and Lactobacillus casei}

Garlic was purchased from a local market in Semarang city. It was peeled, thinly cut, and dried in an oven at $40^{\circ} \mathrm{C}$ until dry. Lactobacillus casei $\left(10^{9} \mathrm{cfu} / \mathrm{g}\right)$ was obtained from the Microbiology Laboratory Gadjah Mada University Indonesia. The isolates were rejuvenated on a petri dish using de Man, Rogosa, and Sharpe (MRS) agar. Lactobacillus casei was incubated for $1 \times$ 24 hours at $37^{\circ} \mathrm{C}$ in $100 \mathrm{ml}$ of $10 \%$ skim milk. Then, it was added with $1.5 \%$ (weight/volume) of garlic powder. The mixture of garlic powder and Lactobacillus casei were incubated for $2 \times$ 24 hours to make mixture of garlic powder and Lactobacilluccasei (GLC). The total plate count method was applied to count the bacterial population in GLC (Usman et al., 2018).

\section{Experimental Design, Ration, and Manage- ment}

A completely randomized design was used in this study. Two hundred 1-day old Lohmann broilers (MB-202) (mean body weight $=44.7 \pm$ $0.52 \mathrm{~g}$ ) were used in this study. Broiler chickens were reared in broiler houses with open sides, for 21 days. Chicks were randomly assigned to 20 experimental units, each unit was consisted of 10 birds. During the study period (1-21 days), the chicks were fed commercial feed containing 14\% water, $21-23 \%$ crude protein, $5 \%$ crude fiber, $5 \%$ crude fat, and $7 \%$ crude ash (nutrient composition obtained from the feed mill company). Drinking water and feed were given ad libitum. Supplements in the form of a mixture of garlic and Lactobacillus casei (GLC) were added at doses of 0 (control), 1\% (GLC1), 2\% (GLC2), and 3\% (GLC3) of total feed.

On the $21^{\text {st }}$ day, 20 birds (one chick per experimental unit) were randomly selected and weighed after fasting for $12 \mathrm{~h}$. Blood was taken and was put into vacutainers containing Ethylene diamine tetra acetic (EDTA) to determine the hematological value. After blood sampling, birds were slaughtered according to Islamic law by cutting the neck of the chicken (Ahmed et al., 2014). The intestinal organs including the duodenum, jejunum, ileum, and caeca were collected, then $\mathrm{pH}$ organs were observed and each organ was weighed. Caeca samples from both ceca were diluted by weight in buffered peptone water. Then, it was homogenized and was analyzed for volatile fatty acids (VFA). Lymphoid organs including bursa of Fabricius, spleen, and thymus were also weighed.

\section{Measurement of Parameters}

The performances of broilers included feed consumption, body weight gain, and feed conversion ratio (FCR) were calculated on the $21^{\text {st }}$ day. The relative weight of immune and visceral organs was calculated by dividing wet organ weight and live body weight. The performance and relative weight of immune and visceral organs were calculated according to Sugiharto et al. (2016), while lactic acid bacteria and coliforms from the intestinal digesta were measured based on the method of Peng et al. (2016). pH values of internal organs were determined by a digital $\mathrm{pH}$ meter in each part of the small intestine following the method of Nabizadeh (2012). The midpoint of the ileum was removed $3 \mathrm{~cm}$ and was fixed in $10 \%$ buffered formalin. The ileum segments were embedded in paraffin, and a $5 \mu \mathrm{m}$ section of each sample was placed on a glass slide and was stained with hematoxylin and eosin to be observed under light microscopy. Measurement of villi height of jejunum was done using a computer with Microsoft Office Picture Manager Program at $10 \times$ magnification. Each slide was measured at least three times. The villus height $(\mathrm{VH})$ was measured from the tip of the 
villus to the villus-crypt junction (Elmi et al., 2020). Twenty replicates were used as the sample, and the average values $\mathrm{VH}$ were used in statistical analysis. Volatile fatty acids (VFA) were analyzed according to Wielen et al. (2000).

During days 21 to 24 , chickens were fed by experimental diet, and all excreta were collected for each replicate. Pooled excreta were mixed, dried, grounded, and analyzed for their proximate. Sample of feed and excreta were analyzed for their proximate by AOAC (2007) for dry matter, crude protein (CP), crude fat, and crude fiber. Nutrient digestibility was determined using the nutrient of feed and excreta. Nutrients (protein, fat and crude fiber) digestibility was measured according to Kong and Adeola (2014), as follows:

Nutrient digestibility $=$

$\left[\frac{\text { (nutrient consumed }- \text { nutrient in excreta) }}{\text { nutrient consumed }}\right] \times 100 \%$

Apparent metabolizable energy (AME) was calculated according to Wealleans et al. (2017):

$\mathrm{AME}=[(\mathrm{FI} \times \mathrm{GED})-(\mathrm{EO} \times \mathrm{GEE})] / \mathrm{FI}$

$\mathrm{FI}=$ feed intake, $\mathrm{GED}=$ gross energy diet; $\mathrm{EO}=$

Excreta output; GEE = gross energy excreta

The N Retention or Ca Retention was calculated by substitution of $\mathrm{N}$ or $\mathrm{Ca}$ diet and $\mathrm{N}$ or $\mathrm{Ca}$ excreta in place of the respective gross energy. The total erythrocytes and leukocytes were calculated according to Sugiharto et al. (2016), using the dilution flask method (cell count using the Bürker chamber), while the differential leucocytes were analyzed using a light microscope. $\mathrm{H} /$ $\mathrm{L}$ ratio was calculated by dividing the numbers of heterophils and lymphocytes.

\section{Statistical Analysis}

Data were analyzed using analysis of variance by SPSS version 22. Significant differences among treatment groups were analyzed using Duncan's multiple range test $(\mathrm{P} \leq 0.05)$.

\section{RESULTS}

\section{The Immune and Visceral Organs}

The data on the relative weight of immune and visceral organs of broiler chickens were presented in Table 1. GLC administration had a significant effect on the relative weight of the bursa of Fabricius $(\mathrm{P} \leq 0.05)$, but it had not shown a significant effect $(\mathrm{P} \geq 0.05)$ on the relative weight of the spleen and thymus. Chickens in the GLC2 and GLC3 have a higher relative weight of the bursa of Fabricius compared to the control and GLC1. The addition of GLC had a significant effect $(\mathrm{P} \leq 0.05)$ on the relative weight of the ileum and caecum, but it had not shown a significant effect on the other viscera organs.

\section{Production of VFA and pH Intestinal}

A diet with supplementation of GLC affected the production of VFA in the caecum (Table 2). Acetate and propionate in the group of chickens that were given GLC diet was higher $(\mathrm{P} \leq 0.05)$ than those in the control group. A diet with GLC significantly decreased $(\mathrm{P} \leq 0.05) \mathrm{pH}$ in the duodenum and ileum (Table 3 ), but $\mathrm{pH}$ of the jejunum, caecum, and colon were the same among treatments.

\section{Nutrient Digestibility}

Diet with GLC supplementation significantly affected nutrient digestibility in starter phase broilers (Table 4). GLC $1-3 \%$ to broiler chickens had a significant effect $(\mathrm{P} \leq 0.05)$ on the increase of protein and crude fiber digestibility, as well as Ca retention.

\section{Blood Parameters}

The effect of GLC supplementation data on blood parameters in broilers were presented in Table 5. Hematological variables of broiler chickens measured that showed a significant difference $(\mathrm{P} \leq 0.05)$ were the heterophil levels, lymphocytes, and the heterophil to lymphocytes $(\mathrm{H} /$ L) ratio. Regarding the $\mathrm{H} / \mathrm{L}$ ratio, the control chickens had the highest $\mathrm{H} / \mathrm{L}$ ratio $(\mathrm{P} \leq 0.05)$ compared to other treatments, while GLC3 showed the lowest H/L.

\section{Performance of Broiler Chicks}

The results of our study in Table 6 showed 
that giving a combination of garlic powder and Lactobacillus casei (GLC) significantly improved $(\mathrm{P} \leq 0.05)$ the performance of broiler chickens $(\mathrm{P} \leq 0.05)$. The increase in consumption in the GLC group was followed by an increase in body weight gain and a decrease in FCR $(\mathrm{P} \leq 0.05)$, but the carcass percentage of all treatments showed the same result $(\mathrm{P}>0.05)$.

\section{DISCUSSION}

Our results showed that GLC supplementation in broiler rations can improve growth performance, nutrient digestibility and FCR of broilers. The results showed that the growth performance of broiler chickens given a mixture of garlic powder and Lactobacillus casei (GLC) at the level of $1-3 \%$ in the rations increased body weight gain compared to control. The results of this study were supported by Lukanov et al. (2018) that garlic powder and Lactobacillus spp. supplementation had a significant effect on broiler's growth performance. Ferdous et al. (2019) also reported that probiotics and phytobiotics improved performance, hematological parameters, and gut microbial load in broiler chicken. Likewise, the combination of the Lactobacillus acidophilus and natural antibacterial (medicinal plant aqueous extracts/ MPAE) in broiler diet increased body weight gain and villus surface area of the jejunum (Elmi et al., 2020). The growth enhancement mecha- nism in broilers is still unclear, but was thought to be influenced by intestinal health, changes in intestinal microbes, immune organs, and increasing nutrient digestibility. This bodyweight gain was inferred to be related to the role of synbiotic GLC, which supported the growth of probiotic bacteria because, in GLC, specific substrates were available for fermentation. Therefore, the host obtained better benefits from this combination of phytobiotics and prebiotics. The increase in probiotic bacteria in the gut leads to increase production of lactic acid and SCFA, which in turn can increase the acidity in the intestine. This can be seen from the intestinal $\mathrm{pH}$ where there is a lower $\mathrm{pH}$ in the duodenum and ileum. The decreased intestinal $\mathrm{pH}$ in GLC group in the present study resembles to the result of Jamroz et al. (2003) and Ferdous et al. (2019), who reported that dietary supplementation of plant extracts in the diet significantly reduced the intestinal $\mathrm{pH}$ of broilers. The decreased $\mathrm{pH}$ in GLC treatment indicates that SCFA found in caecum reduce the number of pathogenic bacteria in the gut, while increasing nutrient digestibility. High acidity reduces the growth of pathogenic bacteria (Song et al., 2014) so that the intestine becomes healthier. In newly hatched chicks in commercial hatcheries, the SCFA concentration and $\mathrm{pH}$ are not sufficient to chemically suppress pathogens (Al-Khalaifah, 2020). Therefore, supplementation of probiotics and phytobiotics will be very beneficial.

Table 1. Relative weight of internal organs and villi height of jejunum of broiler chicks

\begin{tabular}{lcccccc}
\hline Items (\% live body weight; & \multicolumn{4}{c}{ Dietary treatments } & \multirow{2}{*}{ SEM } & \multirow{2}{*}{ P value } \\
\cline { 2 - 5 } unless otherwise noted) & Control & GLC1 & GLC2 & GLC3 & & \\
\hline Spleen & 0.10 & 0.94 & 0.11 & 0.11 & $<0.01$ & 0.48 \\
Bursa of Fabricius & $0.17^{\mathrm{b}}$ & $0.15^{\mathrm{b}}$ & $0.26^{\mathrm{a}}$ & $0.27^{\mathrm{a}}$ & 0.01 & 0.01 \\
Thymus & 0.29 & 0.29 & 0.30 & 0.36 & 0.01 & 0.23 \\
Duodenum & 0.59 & 0.56 & 0.64 & 0.58 & 0.01 & 0.10 \\
Jejunum & 1.27 & 1.22 & 1.32 & 1.40 & 0.03 & 0.14 \\
Ileum & $0.67^{\mathrm{b}}$ & $1.11^{\mathrm{a}}$ & $1.23^{\mathrm{a}}$ & $1.16^{\mathrm{a}}$ & 0.02 & $<0.01$ \\
Caecum & $0.35^{\mathrm{b}}$ & $0.34^{\mathrm{b}}$ & $0.41^{\mathrm{ab}}$ & $0.42^{\mathrm{a}}$ & 0.01 & 0.04 \\
Colon & 0.13 & 0.18 & 0.24 & 0.23 & 0.02 & 0.06 \\
Villi height of jejunum ( $\mu$ m) & 794 & 859 & 872 & 941 & 19.9 & 0.12 \\
\hline a,b Values with different superscript within the same row were significantly different & & \\
Control= broilers receiving ration without GLC; GLC1= broilers receiving 1\% GLC; GLC2= broilers &
\end{tabular}


The improvement of intestinal health is closely related to the growth of digestive tract. In this study, the relative weight of ileum and ceca at day 21 on broiler chickens also increased. Intestinal growth had increased due to GLC supplementation in the ration. Concomitant with this, Sugiharto et al. (2016) reported that feeding probiotic Bacillus plus vitamins and minerals on broiler during starter phase increased the growth and development of ileum. In general, the increased growth of ileum and caeca is associated with the improved digestive function of broilers. Protein and crude fiber digestibility in this study increased, followed by Nitrogen and Calcium retention. Lactobacillus acidophilus supplementation improved nutrient digestibility in broilers (Zhang and Kim, 2014), because it could stimulate digestive enzyme activity (Jin et al., 2000). The increase in digestibility was followed by an increase in absorption because GLC administration tended to increase the height of the intestinal villi. According to Awad et al. (2010) and Song et al. (2014), Lactobacillus supplementation in the diet increased nutrient absorption, which is associated with improved intestinal architecture. Improvements in some of these parameters lead to increase body weight gain of broilers in the starter phase.

The relative weight of bursa of Fabricius was higher in the GLC group than those in the control group. The mixture of GLC can increase the relative weight of immune tissues as also reported by Zhang et al. (2013) and Mangisah et al. (2020). In some cases, the relative weight of immune organs of broiler chickens can reflect responses of immune and functionality (El-Katcha et al., 2014). The positive effect of a diet containing probiotics and phytobiotics (GLC) on the im- mune response is associated with an increase in commensal bacteria in the digestive tract and the response to lymphatic tissue that produces $\mathrm{T}$ and B lymphocytes (Kabir et al., 2004). The commensal bacteria contribute to the growth of the intestinal immune organs and also help in the stimulation of innate and adaptive immune responses (Adil and Magray, 2012). Alkhalf et al. (2010) reported that chickens treated with $1.6 \mathrm{~g}$, $1 \mathrm{~g}$, and $0.8 \mathrm{~g}$ of probiotic per $\mathrm{kg}$ of feed during 42 days showed an increase of the bursa of Fabricius weight. An increase in the relative weight of bursa may be attributed to an increase in the number of immune cells. The study showed that $\mathrm{H} / \mathrm{L}$ ratio of chickens fed GLC2 and GLC3 was lower than those of chickens fed control diet or diet containing $1 \%$ of GLC. This finding suggests that diets with GLC, especially as much as 2 and $3 \%$ of the total rations, may preclude the chickens from infections, inflammation, or stress. These phenolic compounds in garlic powder could act as antimicrobial agents, and prevent the broiler chickens from infections and inflammation (Omer et al., 2019). Garlic contains allicin, alliin, ajoene, diallyl sulfide, dithiin, Sallylcysteine. Garlic as a natural feed additive in poultry nutrition may be of great benefit, because it has antibacterial, anti-inflammatory, antiseptic, antiparasitic, and immune-modulatory properties (Rehman and Munir, 2015). In addition, the high antioxidant activity in the garlic combined with Lactobacillus casei may cope with the oxidative stress that can compromise the immune system. The decreased $\mathrm{H} / \mathrm{L}$ ratio may indicate that chickens were healthy, while the increased $\mathrm{H} / \mathrm{L}$ ratio indicated that chickens suffer from infections, inflammation, or stress (Davis et al., 2008). The $\mathrm{H} / \mathrm{L}$ ratio has recently been used as

Table 2. VFA concentrations of caecal content of broiler chicks

\begin{tabular}{|c|c|c|c|c|c|c|}
\hline \multirow[t]{2}{*}{ Items (mmol/kg) } & \multicolumn{4}{|c|}{ Dietary treatments } & \multirow{2}{*}{ SEM } & \multirow{2}{*}{$\mathrm{P}$ value } \\
\hline & Control & GLC1 & GLC2 & GLC3 & & \\
\hline Acetate & $128^{\mathrm{b}}$ & $192^{\mathrm{a}}$ & $170^{\mathrm{a}}$ & $170^{\mathrm{a}}$ & 3.47 & $<0.01$ \\
\hline Propionate & $13.1^{\mathrm{b}}$ & $22.5^{\mathrm{a}}$ & $17.9^{\mathrm{ab}}$ & $21.7^{\mathrm{a}}$ & 1.05 & 0.02 \\
\hline Butyrate & 36.9 & 31.1 & 36.9 & 29.9 & 2.14 & 0.51 \\
\hline
\end{tabular}


Table 3. pH values of intestinal segments of broiler chicks

\begin{tabular}{lcccccc}
\hline \multirow{2}{*}{ Items } & \multicolumn{3}{c}{ Dietary treatments } & \multicolumn{2}{c}{ SEM } & \multirow{2}{*}{ P value } \\
\hline Duodenum & Control & GLC1 & GLC2 & GLC3 & & \\
Jejunum & $6.00^{\mathrm{a}}$ & $5.74^{\mathrm{b}}$ & $5.84^{\mathrm{ab}}$ & $5.96^{\mathrm{a}}$ & 0.03 & 0.03 \\
Ileum & 5.92 & 6.00 & 5.90 & 6.18 & 0.04 & 0.10 \\
Caecum & $6.62^{\mathrm{a}}$ & $6.10^{\mathrm{b}}$ & $6.20^{\mathrm{b}}$ & $6.34^{\mathrm{b}}$ & 0.04 & $<0.01$ \\
Colon & 6.60 & 6.58 & 6.58 & 6.64 & 0.07 & 0.98 \\
\hline
\end{tabular}

${ }^{\mathrm{a}, \mathrm{b}}$ Values with different superscript within the same row were significantly different

Control= broilers receiving ration without GLC; GLC1= broilers receiving 1\% GLC;

GLC2=broilers receiving $2 \%$ GLC; GLC3= broilers receiving 3\% GLC; SEM= standard error of mean

Table 4. Nutrient digestibility of broiler chicks

\begin{tabular}{lcccccc}
\hline Items & \multicolumn{4}{c}{ Dietary treatments } & \multirow{2}{*}{ SEM } & \multirow{2}{*}{$P$ value } \\
\cline { 2 - 5 } & Control & GLC1 & GLC2 & GLC3 & & \\
\hline Fat digestibility (\%) & 81.3 & 85.1 & 86.2 & 87.9 & 4.11 & 0.21 \\
Protein digestibility (\%) & $79.9^{\mathrm{b}}$ & $83.9^{\mathrm{a}}$ & $84.3^{\mathrm{a}}$ & $86.0^{\mathrm{a}}$ & 0.38 & $<0.01$ \\
Crude fiber digestibility (\%) & $20.9^{\mathrm{b}}$ & $24.4^{\mathrm{a}}$ & $25.7^{\mathrm{a}}$ & $26.7^{\mathrm{a}}$ & 0.43 & $<0.01$ \\
AME (kcal/kg) & 2971 & 3044 & 3164 & 3090 & 22.8 & 0.05 \\
N Retention (g) & 2.26 & 2.05 & 2.41 & 2.29 & 0.08 & 0.42 \\
Ca Retention (g) & $0.16^{\mathrm{b}}$ & $0.19^{\mathrm{b}}$ & $0.28^{\mathrm{a}}$ & $0.20^{\mathrm{b}}$ & 0.01 & $<0.01$ \\
\hline
\end{tabular}

${ }^{\mathrm{a}, \mathrm{b}}$ Values with different superscript within the same row were significantly different

Control= broilers receiving ration without GLC; GLC1= broilers receiving 1\% GLC; GLC2=broilers receivin€

$2 \%$ GLC; GLC3 = broilers receiving 3\%GLC; $\mathrm{SEM}=$ standard error of mean

an indicator of stress conditions in broiler chickens.

The GLC supplementation can decrease intestinal $\mathrm{pH}$ values. Inulin and FOS from garlic powder provides a specific substrate as a "nutrition source" that can be fermented by Lactobacillus casei and increases the growth of Lactobacillus in general in terms of lactic acid bacteria (LAB). The increased growth of LAB is correlated with the higher production of lactic acid and SCFA (acetate, propionate, and butyrate), which correlates with the decrease of intestinal $\mathrm{pH}$. The high concentration of lactic acid affected the decrease in $\mathrm{pH}$ and reduce the growth of harmful bacteria (Nkukwana, et al., 2015). Acidic intestinal conditions affected the growth of intestinal commensal bacteria (LAB). The increase in LAB can increase the production

Table 5. Blood parameters of broiler chicks

\begin{tabular}{|c|c|c|c|c|c|c|}
\hline \multirow{2}{*}{ Items } & \multicolumn{4}{|c|}{ Dietary treatments } & \multirow{2}{*}{ SEM } & \multirow{2}{*}{$P$ value } \\
\hline & Control & GLC1 & GLC2 & GLC3 & & \\
\hline Erythrocytes $\left(10^{6} / \mathrm{mm}^{3}\right)$ & 53.6 & 2.52 & 2.66 & 2.57 & 0.08 & 0.71 \\
\hline Leukocytes $\left(10^{9} / 1\right)$ & 9.13 & 10.3 & 10.5 & 10.4 & 0.36 & 0.51 \\
\hline Hemoglobin $(\mathrm{g} / \mathrm{dl})$ & 7.36 & 7.28 & 7.66 & 7.66 & 0.09 & 0.32 \\
\hline Hematocrit $(\%)$ & 22.8 & 24.2 & 24.0 & 26.0 & 0.74 & 0.52 \\
\hline Total protein plasma $(\mathrm{g} / \mathrm{dl})$ & 1.66 & 2.12 & 2.48 & 2.16 & 0.17 & 0.37 \\
\hline Heterophils $\left(10^{8}\right)$ & $42.6^{\mathrm{a}}$ & $35.0^{\mathrm{b}}$ & $35.0^{\mathrm{b}}$ & $29.4^{\mathrm{c}}$ & 0.83 & $<0.01$ \\
\hline Lymphocytes $\left(10^{8}\right)$ & $53.6^{\mathrm{c}}$ & $59.6^{\mathrm{b}}$ & $57.8^{\mathrm{b}}$ & $64.6^{\mathrm{a}}$ & 0.59 & $<0.01$ \\
\hline $\mathrm{H} / \mathrm{L}$ ratio & $0.79^{\mathrm{a}}$ & $0.59^{\mathrm{b}}$ & $0.61^{\mathrm{b}}$ & $0.46^{\mathrm{c}}$ & 0.02 & $<0.01$ \\
\hline
\end{tabular}

${ }^{\mathrm{a}, \mathrm{b}}$ Values with different superscript within the same row were significantly different

Control= broilers receiving ration without $\mathrm{GLC}$; GLC1 $=$ broilers receiving $1 \% \mathrm{GLC}$;

$\mathrm{GLC} 2=$ broilers receiving $2 \%$ GLC; GLC3 = broilers receiving $3 \% \mathrm{GLC}$; SEM= standard error of mean 
Table 6. Performances of broilers chicks

\begin{tabular}{|c|c|c|c|c|c|c|}
\hline \multirow{2}{*}{ Items } & \multicolumn{4}{|c|}{ Dietary treatments } & \multirow{2}{*}{ SEM } & \multirow{2}{*}{$P$ value } \\
\hline & Control & GLC1 & GLC2 & GLC3 & & \\
\hline$\overline{\text { Feed intake (g/bird) }}$ & 1111 & 1040 & 1185 & 1140 & 12.7 & 0.08 \\
\hline Body weight gain (g/bird) & $660^{\mathrm{b}}$ & $730^{\mathrm{a}}$ & $704^{b}$ & $714^{\mathrm{a}}$ & 8.08 & 0.04 \\
\hline FCR & $1.69^{\mathrm{b}}$ & $1.42^{\mathrm{a}}$ & $1.69^{\mathrm{b}}$ & $1.60^{\mathrm{b}}$ & 0.03 & 0.01 \\
\hline Carcass $(\%)$ & 57.6 & 58.1 & 59.9 & 58.5 & 0.30 & 0.07 \\
\hline
\end{tabular}

${ }^{\mathrm{a}, \mathrm{b}}$ Values with different superscript within the same row were significantly different

Control= broilers receiving ration without GLC; GLC1= broilers receiving $1 \%$ GLC;

GLC2 $=$ broilers receiving 2\% GLC; GLC3= broilers receiving 3\% GLC; SEM= standard error

of volatile fatty acids and bacteriocins, which can inhibit pathogens. The balancing intestinal microbiota of broiler chickens affected the health of gut and growth performance of broiler chickens (Sugiharto, 2016), and its influence was particularly relevant when chickens were young and their microbiota was still in the process of development. The interaction of microbiota, intestinal growth, digestive and nutrient utilization is critical during starter phase.

In this study, supplementation of GLC in the diet did not significantly effect on the number of erythrocytes, leukocytes, hemoglobin, hematocrit, and total protein plasma. Sugiharto et al. (2017) reported that three-week-old broilers had erythrocyte values of 2.15-2.98 $\times 1012 / \mathrm{L}$. Hematocrit in this study was in line with the number of erythrocytes and hemoglobin levels. The GLC supplementation in chicken rations significantly affected heterophils, lymphocytes, and $\mathrm{H} / \mathrm{L}$ ratio. The results of this study were supported by Hanieh et al. (2010), Ao et al. (2011), and Rehman and Munir (2015), who also found that garlic supplementation increased the white blood cells, lymphocytes, and immunoglobulin $\mathrm{G}$ in broilers. The enhanced lymphocyte proliferation by garlic treatment along with the possible protection of the cells from oxidative stress seemed to contribute to the increasing of white blood cells (Rehman and Munir, 2015). Hematological variables in this study showed that giving GLC improved the health of broiler chickens, it is seen from the low value of the $\mathrm{H} / \mathrm{L}$ ratio and the chickens did not experience stress. Hematological variables have commonly been used as indicators of physiological conditions, health, and nutritional deficiency in broiler chickens. The changes in blood profile (hemoglobin, erythrocyte, and differential leukocytes) may indicate stress (Sugiharto et al., 2016).

As a consequence of these improvements in intestinal health, immune organs, nutrient digestibility, and blood parameter, this study found a beneficial effect of GLC supplementation on growth performance, which is in line with previous findings reported by Mangisah et al. (2020) and Wealleans et al. (2017).

\section{CONCLUSION}

Supplementation of GLC on commercial diet improved growth rate, internal organ development, nutrient digestibility, and physiological conditions of broiler chicks during starter phase.

\section{ACKNOWLEDGMENTS}

The Authors extend their gratitude to the Institute for Research and Community Service, Universitas Diponegoro, due to the valuable funding contribution through the "Program Riset Pengembangan dan Penerapan (RPP)", contract number: 233-93/UN7.6.1/PP/2020.

\section{REFERENCES}

Adil, S. and S. N.Magray. 2012. Impact and manipulation of gut microflora in poultry: a review. J. Anim. Vet. Adv. 11: 873-877.

Ahmed, A., I. Zulkifli, A. S. Farjam, N. Abdullah, J. B. Liang and E A Awad. 2014. Effect of solid state fer- 
mentation on nutrient content and ileal amino acids digestibility of canola meal in broiler chickens. Ital. J. Anim. Sci. 13: 410-14.

Al-Khalaifah, H. S. 2018. Benefits of probiotics and/or prebiotics for antibiotic-reduced poultry. Poult. Sci. 97(11):3807-3815.

Alkhalf, M., Alhaj and I. Al-Homidan. 2010. Influence of probiotic supplementation on immune response of broiler chicks. Egypt Poult. Sci.J. 30 (I):271-280.

Ao, X., J. S.Yoo, T. X. Zhou, J. P. Wang, Q. W.Meng, L. Yan, J. H. Cho and I. H. Kim. 2011. Effects of fermented garlic powder supplementation on growth performance, blood profiles and breast meat quality in broilers. Livest. Sci. 141(1):8589.

AOAC. 2007. Official Methods of Analysis. AOAC Int. Gaithersburg, MD, USA.

Awad, W. A., K. Ghareeb, S. Abdel-Raheem and J. Bohm. 2009. Effects of dietary inclusion of probiotic and symbiotic on growth performance, organ weight and intestinal histomorphology of broiler chicken. Poult. Sci. 88: 49-55.

Capasso, A.2013. Antioxidant action and therapeutic efficacy of Allium sativum L. Molecules 18: 690-700.

Davis, A. K., D. L. Maney and J. C.Maerz. 2008. The use of leukocyte profiles to measure stress in vertebrates: a review for ecologists. Funct. Ecol. 22:760-772.

Dixit, S., H.V. Dube, A. K. Dubey and V. P. Singh.2018. Yield and nutrient uptake of garlic (Allium sativum L.) as influenced by sulphur nutrition. J. Pharmacogn. Phytochem. 7(2):1961-1963.

El-Katcha, M. I., M. E. El-Kholy, M. A. Soltan and A. H. EL-Gayar. 2014. Effect of dietary omega-3 to omega- 6 ratio on growth performance, immune response, carcass traits and meat fatty acids profile of broiler chickens. Poult. Sci. J. 2:71-94.

Elmi, V. A., S.Moradi,S. G.Harsini and M.Rahimi. 2020. Effects of Lactobacil- lus acidophilus and natural antibacterials on growth performance and Salmonella colonization in broiler chickens challenged with Salmonella enteritidis. Livest. Sci. 233:103948.

Ferdous, M. F., M. S.Arefin, M. M. Rahman, M. M. R. Ripon, M. H. Rashid, M. R. Sultana, M T Hossain, M. U. Ahammad and K. Rafiq. 2019. Beneficial effects of probiotic and phytobiotic as growth promoter alternative to antibiotic for safe broiler production. J. Adv. Vet. Anim. Res. 6(3):409-415.

Gawad, M. A., M. A. Aziz, M. E. Sayed, E. E. Wakil and E. A. Lateef. 2014. In vitro antioxidant, total phenolic and flavonoid contents of six Allium species growing in Egypt. J. Microbiol. Biotechnol. Food Sci. 3(4):343-346.

Hanieh, H., N. Kiyoaki, P. Mingzi, G. Chaogetu, A. Asaki, K. Yasuhiro. 2010. Modulatory effects of two levels of dietary Alliums on immune response and certain immunological variables, following immunization in White Lenghornchikcens. Anim. Sci. J. 81(6):673680.

Hill, D, I. Sugrue, C. Tobin, C. Hill, C. Stanton and R. P. Ross. 2018. The Lactobacillus casei group: history and health related applications. Front. Microbiol. 9:2107.

Jamroz, D., J. Orda, C. Kamel, A. Wiliczkiewicz, T. Wertelecki and J. Skorupinska. 2003. The influence of phytogenic extracts on performance, nutrient digestibility, carcass characteristics, and gut microbial status in broiler chickens. J. Anim. Feed Sci. 12:583-596.

Jung, S. H., Hong, D. K., Bang, S., Heo, K., Sim, J. and Lee, J. 2021. The functional properties of Lactobacillus casei HY2782 are affected by the fermentation Time. Appl. Sci. 11(2481):2-11.

Kong, C and O.Adeola. 2014. Invited review evaluation of amino acid and energy utilization in feedstuff for swine and poultry diets. Asian -Australas J. Anim. Sci. 27 
(7):917-925.

Kothari, D., W. Lee, K. Niu and S. Kim. 2019. The genus Allium as poultry feed additive: A review. Animals, 91(32):2-21.

Lisciani, S., Gambelli, L., Durazzo, A., Marconi, S. Camilli, E., Rossetti, C., Gabrielli, P., Aguzzi, A., Temperini, O. and Marletta, L. 2017. Carbohydrates components of some Italian local landraces: Garlic (Allium sativum L.) Sustainability. 9 (1922):2-15.

Lukanov, H., I. Pavlova and A. Genchev. 2018. Effect of dietary garlic powder and probiotics supplementation on growth performance of male Ross 308 broilers. J. Agric. Sci. Technol. 10 (1):37-43.

Mangisah, I, L. Krismiyanto, V. D. Yunianto, M. Mulyono, B. Sukamto, F. Wahyono and N. Suthama. 2020. Studies on intestinal ecology and growth performance of Tegal ducks fed with Lactobacillus casei and porang (Amorphophallusoncophyllus) tuber extract. Livest. Res. Rural Dev. 32(8).

Moshfegh, A., J. E. Friday, J. P. Goldman dan J. K. C. Ahuja. 1999. Nutritional and health benefits of inulin and oligofructose. J. Nutr. 129: 1407-1411.

Nabizadeh, A. 2012.The effect of inulin on broiler chicken intestinal microflora, gut morphology, and performance. J. Anim. Feed Sci. 21(4):725-734.

Nkukwana, V, Muchenje, P. J. Masika and B. Mushonga. 2015. Intestinal morphology, digestive organ size and digesta $\mathrm{pH}$ of broiler chickens fed diets supplemented with or without Moringaoleifera leaf meal. S. Afr. J. Anim. Sci. 45:65-70.

Omer, H. A. A, S. M. Ahmed, S. S. AbdelMagid, G. M. H. El-Mallah, A. A. Bakr and M. M. Abdel Fattah. 2019. Nutritional impact of inclusion of garlic (Allium sativum) and/or onion (Allium cepa L.) powder in laying hens diets on their performance, egg quality, and some blood constituents. Bull. Natl. Res. Cent. 43:23.

Peng, Q., X. F. Zeng, J. L. Zhu, S. Wang, X. T. Liu, C. L. Hou, P. A. Thacker and S. Y. Qiao. 2016. Effects of die- tary Lactobacillus plantarum B1 on growth performance, intestinal microbiota, and short chain fatty acid profiles in broiler chickens. Poult. Sci. 98(4):893-900.

Rahman, M. A., D. Ray, M. R. A.Redoy and M. Al-Mamun. 2021. Dose titration of herbs mixture powder supplementation on laying performance and egg quality in commercial layer chicken. Livest. Res. Rural Dev. 33 (1).

Rehman, Z. and M. T. Munir. 2015.Effect of garlic on the health and performance of broilers. Veterinaria. 3(1):32-39.

Song, J., K. Xiao, Y. L. Ke, L. F. Jiao, C. H. Hu, Q. Y. Diao, B. Shi, X. T. Zou. 2014. Effect of a probiotic mixture on intestinal microflora, morphology, and barrier integrity of broilers subjected to heat stress. Poult. Sci. 93:581-588.

Sugiharto, S. 2016. Role of nutraceuticals in gut health and growth performance of poultry. J. Saudi Soc. Agric. Sci. 15:99-111.

Sugiharto, S., T. Yudiarti and I. Isroli. 2016. Haematological and biochemical parameters of broilers fed cassava pulp fermented with filamentous fungi isolated from the Indonesian fermented dried cassava. Livest. Res. Rural Dev. 28(4).

Sugiharto, S., T. Yudiarti, I. Isroli, E. Widiastuti and F. D. Putra. 2017. Effect of dietary supplementation

with Rhizopusoryzae or Chrysoniliacrassa on growth performance, blood profile, intestinal microbial population, and carcass traits in broilers exposed to heat stress. Arch. Anim. Breed. 60:347-356.

Usman, N. A, K. Suradiand, J. Gumilar. 2018. The effect of concentration lactic acid bacteria Lactobacillus plantarum and Lactobacillus casei on microbiology and chemistry properties of mayonnaise probiotic. Jurnal Ilmu Ternak. 18(2):79-85.

Wealleans, A. L., M. C. Walsh,_L. F. Romero and V. Ravindran. 2017. Comparative effects of two multi-enzyme combinations and a Bacillus probiotic on growth performance, digestibility of energy and nutri- 
ents, disappearance of non-starch polysaccharides, and gut microflora in broiler chickens. Poult. Sci. 96:4287-4297.

Wenk, C. 2003. Herbs and botanicals as feed additive in monogastric animals. Asianaustralas. J. Anim. Sci.16:282-9.

Wielen, P., S. Biesterveld, S. Notermans, H. Hofstra, B. A. Urlings and F. Knapen. 2000. Role of volatile fatty acids in development of the cecal microflora in broiler chickens during growth. Appl. Environ. Microbiol. 66(6):2536-2540.

Zhang, Z. F., J. H. Cho and I. H. Kim.
2013. Effects of Bacillus subtilis UBT$\mathrm{MO} 2$ on growth performance, relative immune organ weight, gas concentration in excreta, and intestinal microbial shedding in broiler chickens. Livest. Sci. 155:343347.

Zhang, Z. F. and I. H. Kim. 2014. Effects of multistrain probiotics on growth performance, apparent ileal nutrient digestibility, blood characteristics, cecal microbial shedding, and excreta odor contents in broilers. Poult. Sci. 93(2):364-70. 